\title{
Under Beautiful Chinese Sight Flowers and Plants Enterprise Independent Innovation Development Pattern Research--- Take Zhejiang SENHE Seed co Ltd. as Example
}

\author{
G.L.ZHANG \&B.YU \\ TianMu college, Zhejiang A \& F University, Zhuji, China
}

\begin{abstract}
Beautiful China" is the Chinese nation in building a better home dream, is a symbol of China's modernization, but also a symbol of the great rejuvenation of the Chinese nation. The development of flower seedling industry has very important realistic significance and far-reaching impact on the beautiful Chinese construction. It can not only produce good social and environmental benefits, obtain a higher economic efficiency, more important is to construct is closely related to construction, development of flower and seedling industry and new rural area of socialism harmonious society.. On the domestic infrastructure and rural development has played an exemplary role. Flower enterprises basically rely on technological progress, dependent development mode change development mode to innovation drive from the resources, to promote the sustainable development of flower industry.
\end{abstract}

KEYWORD: Beautiful China; SENHE Seed co Ltd; Innovation pattern; Enlightenment

\section{BACKGROUND}

"Beautiful china, color first, ecological civilization, takes root". 18th National Congress of CPC proposed a "beautiful China" "beautiful China" is the dream of Chinese nation to build a beautiful homeland, is a symbol of China's modernization, and is also a symbol of realizing the great rejuvenation of the Chinese nation. Colorized motherland is the important way to realize China's beautiful and effective way, which is also SENHE's slogan. In 2012, SENHE, as industry leading enterprises, gain the "The stereo virescence series product innovation award". SENHE is becoming a leader of industry, which the capital has increased by 100 times, business area expand 22 provinces, the products' variety, shape and structure has reached 50 categories, more than 500 varieties and more than 5000 products. SENHE has played a demonstration leading role for domestic facilities and development of agriculture, rural areas and farmers.

\section{THE DEVELOPMENT OF SENHE SEED LTD}

\section{1 "SENHE" -A Tale of the East}

SENHE founded in 2000, is a collection of R\&D, scale production, application demonstrate and efficient marketing, in the flowers and trees production science and technology joint-stock enterprises, is a national high-tech enterprise, is also the first seed industry in Zhejiang province. Company put "beautify homeland and colorful motherland" for the enterprise vision, adhering "science and technology leading industry, service creating the market" as business philosophy, and actively committed to the industrialization of seed seedling industry in China, which have been named as "the backbone of agricultural leading enterprises in Zhejiang province" by Zhejiang government. SENHE is bearing one of the Zhejiang provincial five Seed Seedlings Projects. Company adhere to science and technology as the guide, focus on improving product' technology content, actively play the advantages of Corporate Governance, guided by the modern enterprise' management concept, establish a good management mechanism, produce a batch of excellent new products with high-tech content, in order to realize rapid development of enterprises. Companies has 11 wholly owned subsidiaries, 8 branches and 6 regional offices, more than 500, master staff, including more than 30 doctors and masters, above 90\%college degree employees, nearly 90 senior titles' people. Company has passed the certification of quality management system and environmental system, for many years been rated as AAA grade credit enterprise, has selfimportation. At the end of 2011, the company's total asset is about RMB 3 billion. 
The company pioneered the use of modern business operation mode in A\&F corporations, which is" Industrial transformation, commercialization orientation, specialized production and scale management". The company successful created the management system of "separation of production and sales", continuously introduce new varieties, new technologies, new products, new work, new model and new mechanism, continuously explore a variety of business model of China's national conditions, such as the modern R\&D production base of flowers and plants, hypermarket chain of flowers and trees, modern high-tech industrial park, the flowers' theme park, Zero risk plan and prospective field system, which raise a shock wave in the industry and created the "phenomenon of SENHE". SENHE gained many titles in recent years, such as "Chinese modern gardening leader", "Chinese flower industry flagman", "Chinese green industrial upgrading booster", "Chinese modern agriculture development model", "National high-tech enterprise", "National flower production demonstration base". In 2010, the company was rated as "national top ten flowers and trees planted enterprises", and won "silver rose" in "International annual growers".

\section{THE DEVELOPMENT MODLE OF SENHE IN SELF-DEPENDENT INNOVATION}

The thought of SENHE Innovative Concept is: Push SENHE high-seed development and accelerate the progress of the whole industry; Innovative products' research and development; promote the development of modern agricultural science and technology; Innovative new $A \& F$ business model; drive the brand of SENHE enduring; promote industrial upgrading; Innovate marketing system of modern horticultural products; transfer SENHE brand from the professional brand to public brand.

\subsection{The model of company+ peasant household}

SENHE initial business model is the "company plus farmers". In our country, rural collective land use right circulation began in the late $80 \mathrm{~s}$, which is a larger degree to consolidate and promote the household contract responsibility system, and promote the development of rural economy. However, there are some defects: 1 . The power of contractual right of land is too small, because "Agricultural Law " regulate, only in the Auftraggeber agreed, the subcontract or transfer of right to the contracted management of land is legal. 2 . Law has certain hysteresis. The current rural land use right not only subcontract and transfer, also have rental, Shares, mortgage, thus, the law is not clear specification. 3. The trapped of agricultural modernization and industrialization, because there is too scattered in the transfer progress of the contracted land.

\subsection{The model of quasi land-stock}

As an enterprise of agriculture, land is the most important problem. And current land policies objectively did against the development of modern and large-scale agricultural enterprises. Although SENHE has more than 20000 acres of production base in the country, is still unable to satisfy the market demand. Therefore, SENHE launch the model of quasi land-stock.

Quasi land-stock is targeted at some certain strength financial and engaged in a certain basis of nursery stock companies and farmers. Farmers with land, labor, and other factors of production to "share"; the company is "share" with new varieties, new seedlings, and provide free technical guidance, the two sides has equity investment and equity dividends (finished product, finished product seedlings). Which use the theory of "land-stock ", according to the principle of "company + peasant household" and industry to create a win-win mode of flowers and trees production. By 2008, SENHE have accumulated $508000 \mathrm{mu}$ to promote this mode, realize the output value 3.66 billion Yuan, to drive 121000 peasant households, help the farmers' income increase to 1.83 billion Yuan, salve 12000 farmer employment each year.

\subsection{The model of science-technology demonstration garden}

Zhejiang SENHE co., LTD. put forward the development of agricultural science and technology demonstration garden business model, using the base radiation to drive the development of agriculture, rural areas and farmers. This model makes the company's technology rose to a new level, and the company has gradually formed its own technical team, which composed by professors and researchers come from Zhejiang university, Zhejiang A\&F university in the process of development. Obviously, the company is a leading position in technology.

Agricultural science and technology demonstration garden is model is formed in the process of changing from extensive to intensive, the main characteristics is technology intensive, with science and technology development, demonstration, radiation and promotion as the main content, promote regional agriculture structure adjustment and industrial upgrading as the goal. To broaden the scope of the park construction unceasingly, to break the current form of the single mode of factory, greenhouse cultivation, to surrounding agricultural science and technology in different production, increase peasants' income. 
In the business model, put "benefit-sharing, risksharing" for the principle, using product, technology and service as a link, using their own advantages, selectively involved in agricultural production, processing, distribution and sale link, effectively promote value-added agricultural products, promoting the industrialized operation of agriculture, increase farmers' income. Highlighted the role of agricultural science and technology, formed new varieties of new technologies introduced, standardized production, agricultural products processing, marketing, logistics and other various forms of demonstration garden network. Modern agricultural science and technology demonstration garden played a typical demonstration of the traditional agriculture transfer to modern agriculture, explore the traditional agriculture transfer to high yield, high efficient and high quality, played the whole service function in the service of agriculture.

Economic benefit brought by the agricultural science and technology demonstration garden is very significant. For example, the Fuchuangjiang base, which is located in the Fengshan village was named "characteristic agriculture demonstration park" by local county. there are 50000 strains of color lump seedlings to Jiangsu, Henan, Hubei and other places of warm winter climate each day, brought considerable income to SENHE.

\subsection{The model of Industrial park}

the gathering carrier of Industrial park, is main components relevant cultural creative design enterprises, companies offering technology support, such as digital network technology companies, international planning and information consulting and other intermediary agencies; And engage in cultural creative products production enterprises and rich experience in operation of brokerage, etc. This mutual connection of enterprise clusters, constitute a three-dimensional multiple mixed industry chain, to improve the innovation ability and economic benefit has practical significance.

\subsection{Corporate culture of SENHE}

(1). SENHE business philosophy: science and technology to guide industry, services to create market;

(2).SENHE management aim: shake hands with SENHE, create brilliant;

(3).SENHE belief: "S" sincere service customer; "E" exceed customer expectation; "N" new and high technology products;" $H$ " harmonious environment; "E" ever pursue innovation;

(4).SENHE creed: market demand as the driving force of the company; Essentially, the company is the pursuit of high-quality products and services technology companies; The success of the company's most important criteria: customer satisfaction, shareholder satisfaction, employee satisfaction; Company always focus on performance outstanding employees; Companies need to outstanding, has the dedication, especially employees with team work spirit.

(5). SENHE code of conduct: oriented product development and production as customer; Take the customer's way; oriented management as successful performance; Clear career plan to attract talents; Pay attention to our value (collective); First action, as long as there is $80 \%$ hope decision; The key type into.;

(6).SENHE values: customer first; quality for basis; operations team; Innovation; feet on the ground; focus on results;

(7).SENHE management idea: let every corner of SENHE have sunshine; make appreciate moist each soul; make praise with every action; make smiles encourage our dreams;

(8).SENHE management principles: high efficient execution, refused the excuse; attention to detail, pursue the perfect.

\section{THE ENLIGHTENMENT OF INDEPENDENT INNOVATION DEVELOPMENT MODEL BY SENHE SEED INDUSTRY}

\subsection{Innovate management idea, promote the traditional industry upgrade}

SENHE seed industry put" science and technology guide the industry, services create the market" as management idea. This management idea not only make the enterprise get high-speed development, and promote the traditional agriculture industry upgrading, and for the Chinese local flower industry connect with international varieties of flower industry, explore a success path. SENHE officially launched against China flower gardening industry, especially the Midwest horticulture, named "industrial upgrading booster action". This action shows that the innovation of enterprise accumulation is help the foundation of industry and industrial upgrading. The core of the development of creative industry is to build creative industry chain, and extends as far as possible, to form scale merit, obtain the maximum economic benefit and social benefit.

\subsection{Innovate technology research and development, accelerate the modern agriculture technology progress}

In recent years, the central proposed the strategic target of constructing innovative countries, and its purpose is through strengthening the independent innovation as the main means speed up the adjustment of economic structure, gradually promote the transformation of economic growth mode from 
extensive to intensive, to realize the development of economy steady, healthy and sustainable. However, Chinese agriculture, production technology is backward, per unit of output is low, industrial structure is unreasonable, profit is not high, which have become an important factor to restrict the development of the agricultural industry. Therefore, the central is focus on development of modern and efficient facilities agriculture as future direction and important means to break the dilemma of the agriculture. We believe that the key is developing modern agriculture, including speed up the agricultural production, improve agricultural production technology and product value. However, Agriculture technology innovation is ignored "corner" by the market, technology, capital, the reason is agricultural technological innovation is a poor basis and low profits, high risks and other reality conditions. Therefore, speed up the building from the aspects of policy, capital, market has very important significance for the development of modern agriculture. SENHE model can be a good example for the practices of agricultural development.

\subsection{Innovate organization system, speed up the development of modern agriculture}

Backward mode of production, simple structure and old operation mode is an important reason of our country's agricultural development is slow. Developing modern agriculture is not only to realize innovation in technology, but also to innovate in above aspects. SENHE created new path in enterprise ownership structure, governance structure, management system, operational mechanism and the market system, which will help Chinese agricultural reform of organizational structure. SENHE seed industry innovate a kind of "quasi land-stock ", solve the restriction of the land for production, and also effectively promote the farmers' income."Quasi landstock mode" provides a good experience for the poor areas and underdeveloped areas in China, which change from blood-transfusion poverty alleviation and switch to better blood-making function for poverty alleviation.

\subsection{Pay attention to innovate talent mechanism, maximize talent effect}

Talent is the most decisive elements of productivity, is the most important resource of realizing the goal. Respect science, respect knowledge, respect talents, is the key of SENHE seed industry rapid growth. SENHE seed industry provides each employee a relaxed, harmonious, democratic work environment, give every managers the opportunity to fully express their opinion,. Especially, the introduction of "BBS management model", grain staff a broad and directly stage to communicate. This information exchange platform known as the "information flat", it is also one of the important measures by SENHE to adhere "people-oriented, humanized management", embodies the SENHE attaches great importance to the talents.

\subsection{Innovate marketing methods, and constantly exploit new markets}

SENHE layout 4 R\&D bases, 20 modern standard production bases, 30 nursery stock chain stores, 30 flowering chain stores, 40 (the first) "flower garden center", make the enterprise become a research and development production base. Varieties of SENHE production bases set up take "technology airborne local to foster, area radiation " as mode, make the base of the construction and production more efficiency; the chain stores of SENHE is established on the dozens of exhibition, reserves, information, sales, distribution and other multi-functional center.

\subsection{Speed up the economic change, and promote the optimized development of characteristic industry}

Innovation is the soul of a country, is also the source of the enterprise. Comrade HU jintao pointed out that the innovation is strategic support to improve the social productive forces and national strength, must be placed in the core position of the national development, condensation of the whole society's wisdom and strength in the innovation is better to our country. The development of flowers and plants nursery stock industry not only restrict by capital, labor and other inputs and technology level, but also by time (season), space (regional climate characteristics), thus, it can't completely rely on large-scale, standardized production, that is can't just rely on large enterprise in industry organization form, and should be formed in the nationwide industrial concentration area, rely on other small and medium-sized enterprises cluster network to complete. SENHE always put innovation in the first, always cling to different key point in different development period. Apply independent innovation into flowers and plants nursery stock industry, guide the related enterprise to practice of flower seedlings, to effectively guide sustainable development of flower industry.

\section{REFERENCES}

[1] Porter M.E. The competitive advantage of Nation. New York: The Free Press. 1990.

[2] Guoliang ZHANG. Strategic management. Zhejiang: Zhejiang university publisher, 2008 